Article

\title{
Mechanism of Ampicillin Degradation by Non-Thermal Plasma Treatment with FE-DBD
}

\author{
Joshua B. Smith, Isaac Adams (D) and Hai-Feng Ji * \\ Department of Chemistry, Drexel University, Philadelphia, PA 19104, USA; jbs88@drexel.edu (J.B.S.); \\ isaac.d.adams@gmail.com (I.A.) \\ * Correspondence: hj56@drexel.edu; Tel.: +1-215-895-2562; Fax: +1-215-895-1265
}

Received: 8 August 2017; Accepted: 10 October 2017; Published: 27 October 2017

\begin{abstract}
This research focused on determining the effectiveness of non-thermal atmospheric pressure plasma as an alternative to advanced oxidation processes (AOP) for antibiotic removal in solution. For this study, $20 \mathrm{mM}(6.988 \mathrm{~g} / \mathrm{L})$ solutions of ampicillin were treated with a floating electrode dielectric barrier discharge (FE-DBD) plasma for varying treatment times. The treated solutions were analyzed primarily using mass spectrometry (MS) and nuclear magnetic resonance spectroscopy (NMR). The preliminary product formed was Ampicillin Sulfoxide, however, many more species are formed as plasma treatment time is increased. Ampicillin was completely eliminated after five minutes of air-plasma treatment. The primary mechanism of ampicillin degradation by plasma treatment is investigated in this study.
\end{abstract}

Keywords: nonthermal plasma; DBD; antibiotic removal; Ampicillin

\section{Introduction}

According to a joint study between the USA and England in 2014 [1], 50,000 people die in England and United States because of antibiotic-resistant "superbugs" every year. This is consistent with an estimate from Centers for Disease Control and Prevention (CDC) that antibiotic-resistant bacteria caused 23,000 deaths, and two million illnesses each year in the USA [2]. The number of deaths in Asia is more than a half million each year. If no action is taken, according to the current pace of development, millions of people worldwide will die of "superbugs" every year in the late 21st century.

During the last decade, it has been realized that antibiotic-containing wastewater is a severe class of water contamination [3-5]. Due to the intensive use of antibiotics in agriculture, and in human and veterinary medicine, antibiotics are continuously released into the environment [6-8]. Antibiotics and antibiotic residues are excreted without treatment and end up in sewage. The extensive use of antibiotics and their release into environment without treatment is the one of the major causes of the outbreak of antibiotic-resistant pathogens in recent years.

Most of the efforts to combat the growing threat from antibiotic-resistant pathogens focus on the reduction of the use of antibiotics or the development of new antibiotics. However, since most antibiotics are used in livestock production [9], and the majority of antibiotics released into the environment come from livestock farms, hospitals, animal clinics, and pharmaceutical companies, a more practical and cost-effective solution is to remove or decompose antibiotics from their wastewater before release. This approach will have the least impact on the current usage of antibiotics and the economy.

Traditional wastewater treatment methods, such as conventional activated sludge (CAS) [10], membrane processes [11,12], activated carbon adsorption treatment [13-16], cannot effectively remove or inactivate antibiotics. Chlorination is a powerful and effective method to disinfect wastewater, which is used worldwide. However, this method suffers from two major drawbacks: (i) the safe 
storage, transportation, and handling of chlorine; and (ii) the formation of chlorinated byproducts. Advanced oxidation processes represent efficient methods for wastewater treatment $[17,18]$. These processes include Fenton oxidation [19-21], ozonation [22], heterogeneous photocatalysis with $\mathrm{TiO}_{2}$ [23,24], sonolysis [25], and ultraviolet (UV) irradiation photolysis [26,27]. However, all of these method have substantial drawbacks, such as low efficiency due to the $\mathrm{pH}$ of wastewater [28-30], limitation to certain antibiotics [31,32], high energy consumption [33], etc. In summary, there is a need for a treatment for liquid medical waste that is more efficient, lower in cost, less toxic, does not pose logistical challenges, and is simpler and safer to use.

Recently, it was observed that plasma, especially floating electrode dielectric barrier discharge (FE-DBD), effectively decomposed organic chemicals [34-38]. DBD is used to generate a non-thermal plasma under atmospheric pressure conditions by applying a discharge between two electrodes with at least one being covered by a dielectric layer [39-41]. A nanosecond pulsed power supply is used to prevent the buildup of charge on the dielectric surface and allows for a more uniform discharge for an even plasma treatment [42]. This discharge generates a number of reactive oxygen species (ROS) and reactive nitrogen species (RNS), such as superoxide, hydroxyl radicals, nitric oxide, and nitrogen dioxide [38]. When applied above a liquid interface, these species can be generated in solution along with hydrogen peroxide for decomposition of organic chemicals. Previous work on the decomposition of organic species focused on pollution issues and clinical applications [43-45].

We demonstrate in this work the decomposition of ampicillin, a beta-lactam type of antibiotic, under non-thermal DBD plasma as an example of antibiotic removal by using DBD. Of the antibiotic classes, penicillin leads the way in the number of prescriptions and overall usage and their degradation products have been well studied [46-48]. For this reason, ampicillin has been selected as the molecule of choice to study the degradation from FE-DBD plasma treatment. In 2011, Magureanu et al. [49] reported the decomposition of several antibiotics, including ampicillin, by using DBD, but only three to four decomposition products from each antibiotics were analyzed, which did not provide enough information on whether each ampicillin decomposition product has antibiotic properties and whether the decomposition products are toxic to normal cells. We demonstrate the comprehensive studies on the decomposition products and decomposition mechanism of ampicillin under DBD, which is critical to fully understanding their interaction with bacteria and viruses in the environment before large scale applications are employed.

\section{Materials and Methods}

\subsection{Chemicals and Sample Preparation}

Ampicillin and caffeine were purchased from Alfa Aesar. Deuterium oxide was purchased from Sigma Aldrich, (St. Louis, MO, USA). Twenty $\mathrm{mM}$ of ampicillin fresh stock solutions were made with $1 \mathrm{~mL}$ aliquots pulled for each sample treatment. Samples to be run with ${ }^{1} \mathrm{H}$ NMR analysis were prepared with $\mathrm{D}_{2} \mathrm{O}$ prior to plasma treatment. Immediately after plasma treatment, the samples were transferred to a 5-mm NMR tube without dilution. For quantitative studies, each NMR tube was equipped with a sealed capillary of a $10 \mathrm{mM}$ caffeine solution in $\mathrm{D}_{2} \mathrm{O}$ to be used as an external standard. Samples prepared for MS analysis were run in deionized water with the majority of the analysis being done neat. As necessary, samples were diluted 1:20 in $\mathrm{MeOH} / \mathrm{H}_{2} \mathrm{O} /$ formic acid (50/50/0.01) by volume. UV-VIS and fluorescence analysis were performed on samples without further dilution.

\subsection{Plasma Setup and Treatment}

Plasma was generated using a nanosecond-pulsed power supply with alternating polarity (FPG 20-N, FID Technology, (Burbach, Germany) and a floating electrode-dielectric barrier discharge setup (Scheme 1) identical to that used by $\mathrm{Li}$ et al. [50]. This pulse generator provided a 1-10 ns pulse width with a rise time of $5 \mathrm{kV} / \mathrm{ns}$ between the dielectric barrier electrodes [51]. The power supply provides an adjustable frequency of $500 \mathrm{~Hz}$ to $1.5 \mathrm{kHz}$ with a maximum amplitude of $20 \mathrm{kV}$. A 
1-mm thick quartz glass acts as the insulating layer for the high-voltage copper electrode. Plasma was applied to the sample at a fixed gap of $1 \mathrm{~mm}$ using a specialized quartz plate $(87 \times 52 \mathrm{~mm})$ with a $1 \mathrm{~mm}$ deep groove $(57 \times 32 \mathrm{~mm})$ to hold $1 \mathrm{~mL}$ of sample solution. Samples were treated under atmospheric conditions with no gas flow. The parameters for the plasma generation were held steady for the treatment of all samples at $11.2 \mathrm{kV}$ and $690 \mathrm{fHz}$ with only treatment times being varied.

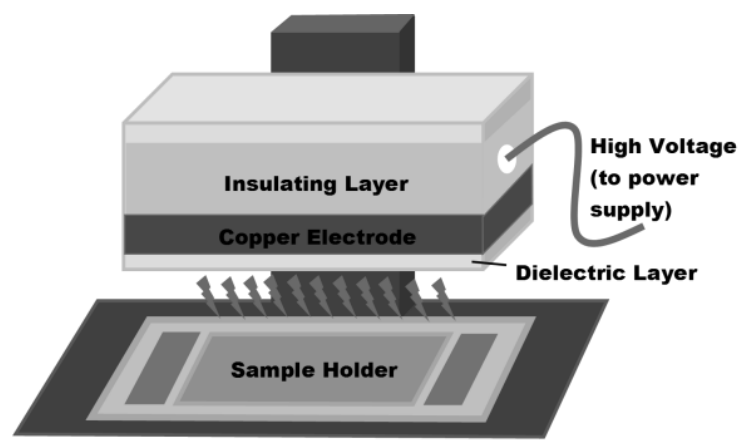

Scheme 1. FE-DBD schematics for plasma treatment of solutions.

\subsection{Instrumentation}

${ }^{1} \mathrm{H}$ NMR spectra were recorded on a $500 \mathrm{MHz}$ Varian Unity Inova spectrometer (Palo Alto, CA, USA) in $5 \mathrm{~mm}$ NMR tubes. An electron spray ionization (ESI) source was used with positive ion mode for mass spectrometry analysis on a Thermo-Finnigan LTQ-Fourier transform ion cyclotron resonance (FT-ICR) mass spectrometer (Waltham, MA, USA). Excitation and emission spectra were collected using a Hewlett Packard 8453 UV-VIS spectrophotometer (Palo Alto, CA, USA) and a Hitachi F-7000 fluorescence spectrophotometer (Tokyo, Japan), respectively.

\section{Results and Discussion}

\subsection{AMP Degradation}

The response of AMP solutions with varying plasma treatment times was first monitored with NMR spectroscopy.

Figure 1 shows the structure and assignment of the ${ }^{1} \mathrm{H}$ NMR chemical shifts for AMP according to published results $[48,52]$. The first region of interest is in the lower range where two singlets are observed from the $\mathrm{CH}_{3}$ protons around $1.42 \mathrm{ppm}$. The second region of interest ranges from 4 to $6 \mathrm{ppm}$ and includes four additional proton signals. It should be noted that these samples were run within $1 \mathrm{~h}$ without modification directly after treatment to best understand the plasma treatment process. For this reason, signals from the protons on the nitrogen and oxygen species were not visible from the proton exchange with deuterium. The decrease in the concentration of the AMP could be monitored by observable changes in these characteristic regions.

\begin{tabular}{|l|l|}
\hline Hydrogen & Chemical Shift \\
\hline $\mathrm{CH}_{3}$ & $1.42(\mathrm{~s})$ and $1.43(\mathrm{~s})$ \\
\hline $\mathrm{H}-4$ & $4.15(\mathrm{~s})$ \\
\hline $\mathrm{H}-17$ & $5.22(\mathrm{~s})$ \\
\hline $\mathrm{H}-2$ & $5.52(\mathrm{ABq})$ \\
\hline $\mathrm{H}-6$ & $5.52(\mathrm{ABq})$ \\
\hline $\mathrm{H}-$ Arom & $7.49-7.55(\mathrm{~m})$ \\
\hline
\end{tabular}

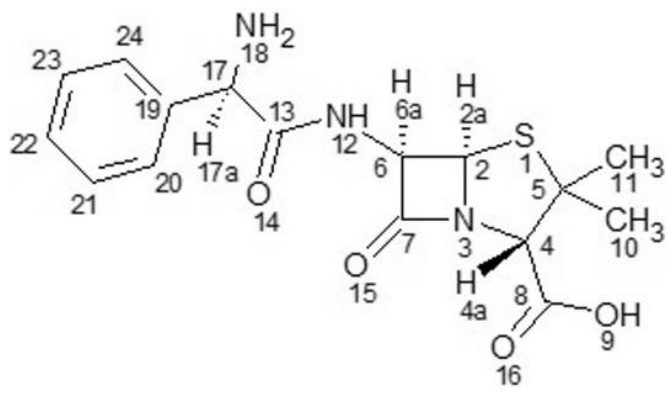

Figure 1. The structure and ${ }^{1} \mathrm{H}$ NMR assignments for ampicillin. 
The decrease in the AMP concentration was apparent with an increase in plasma treatment time and the NMR of AMP versus plasma treatment time is shown in Figures 2 and 3. The decomposition of AMP can be observed as it was immediately noticeable from the decrease in intensity of the two singlets located at 1.42 and $1.43 \mathrm{ppm}$.

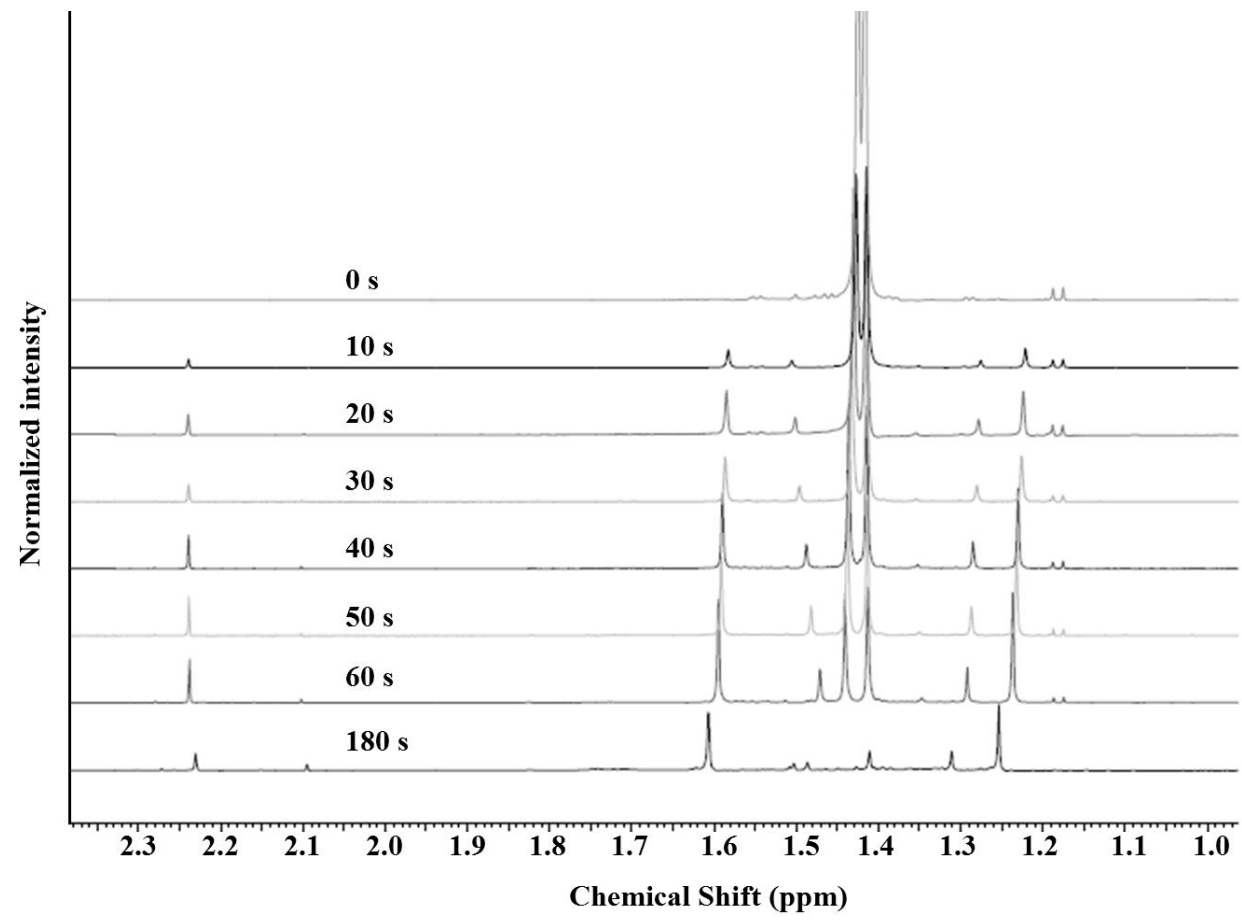

Figure 2. ${ }^{1} \mathrm{H}$ NMR of AMP solutions in $\mathrm{D}_{2} \mathrm{O}$ at increasing plasma treatment time from 0 to $180 \mathrm{~s}$ showing the region containing $\mathrm{CH}_{3}$ protons.

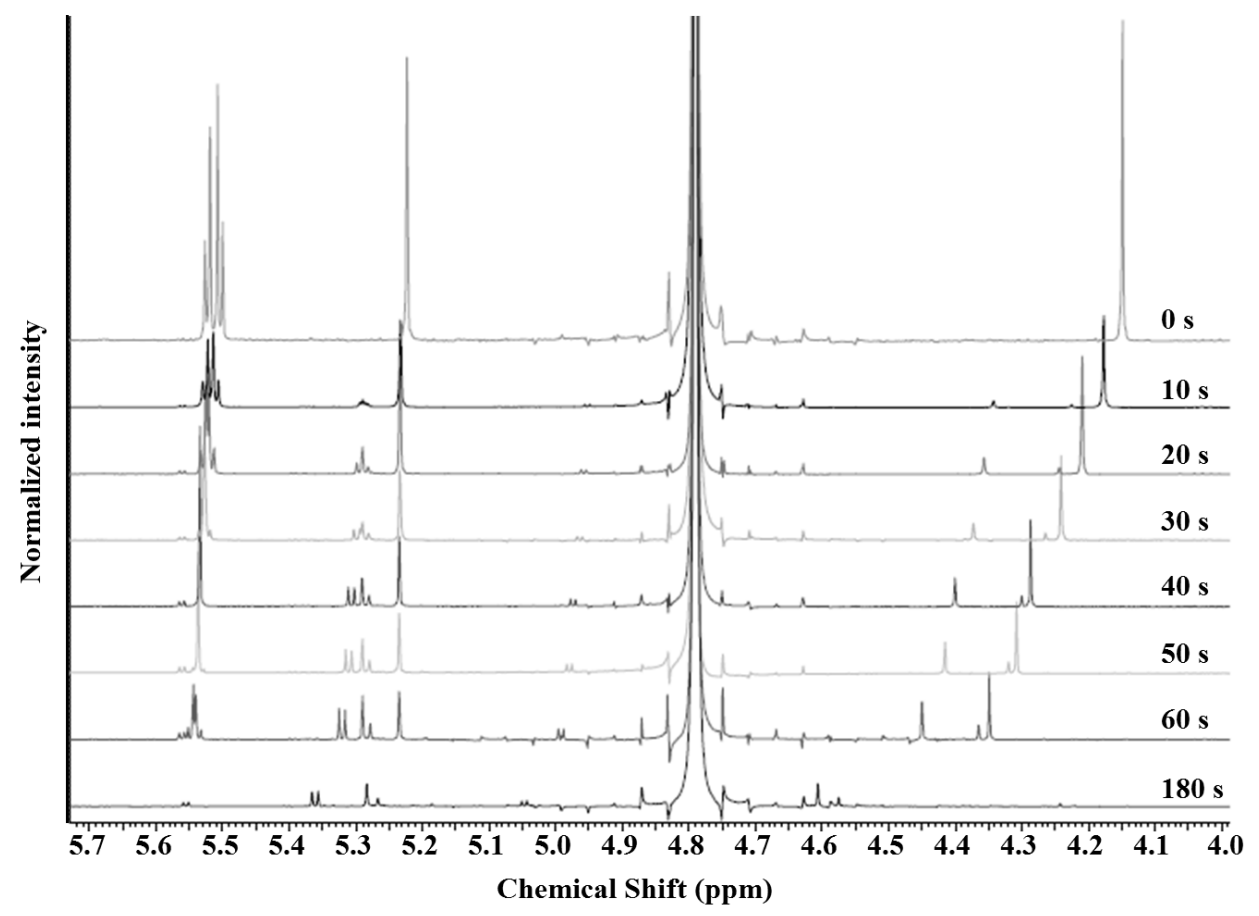

Figure 3. ${ }^{1} \mathrm{H}$ NMR of AMP solutions in $\mathrm{D}_{2} \mathrm{O}$ at increasing plasma treatment time from 0 to $180 \mathrm{~s}$. 
The peaks were also monitored with protons $\mathrm{H}-4$ and $\mathrm{H}-17$, as these are also both singlets and had no interference from other overlapping peaks. From the NMR, no remaining AMP was observed after 3 min of plasma treatment. One apparent change of the NMR is the shift of the H-4 proton. This can be attributed to the significant decrease in the $\mathrm{pH}$ of the solution. The first formation of a new compound was determined by the appearance of two new singlets forming at $1.23 \mathrm{ppm}$ and $1.60 \mathrm{ppm}$. These signals occur from modifications close to the two methyl groups, as a major change in their environment is causing the further separation of these signals. This was attributed to oxidation of the sulfur, as this modification places one of the $\mathrm{CH}_{3}$ groups into a cis position with the oxygen and results in a trans-positioning with the other $\mathrm{CH}_{3}$ group. The methyl group in the cis-position is in closer proximity to the oxygen, which causes deshielding and a shift downfield [53]. A visible shift in H-4, and even splitting of the H-2 and H-6 peaks were caused by this oxidation, as well [54]. Another species that was discernable from the NMR data was the presence of the penicilloic acid of ampicillin. This ampicilloic acid was measured by the two singlets located at $1.18 \mathrm{ppm}$ and $1.19 \mathrm{ppm}$, representative of the methyl protons, and was found in the stock solution of the AMP. This species, however, was not found to be a major product and was not continually formed, as might be expected from the hydrolysis of the $\beta$-lactam ring. Some hydrolysis of the $\beta$-lactam ring was observed and this can be attributed to the continuous signals occurring at 1.18 and $1.19 \mathrm{ppm}$. Oxidation of the ampicilloic acid occurred initially at the sulfur position and resulted in the separation of the methyl singlets to 1.27 and $1.51 \mathrm{ppm}$, as discussed above, however, it is unlikely that this species survived for long and this will be discussed further.

FTIR studies also verified the formation of the $\mathrm{S}=\mathrm{O}$ functionality [55] along with the breakdown of the $\beta$-lactam ring $\left(1764 \mathrm{~cm}^{-1}\right)$. The addition of a caffeine external standard allowed for quantitative monitoring with NMR spectroscopy. Integration of the sample signals representative to the external standard showed a very linear degradation pattern with respect to increased plasma treatment time (Figure 4).

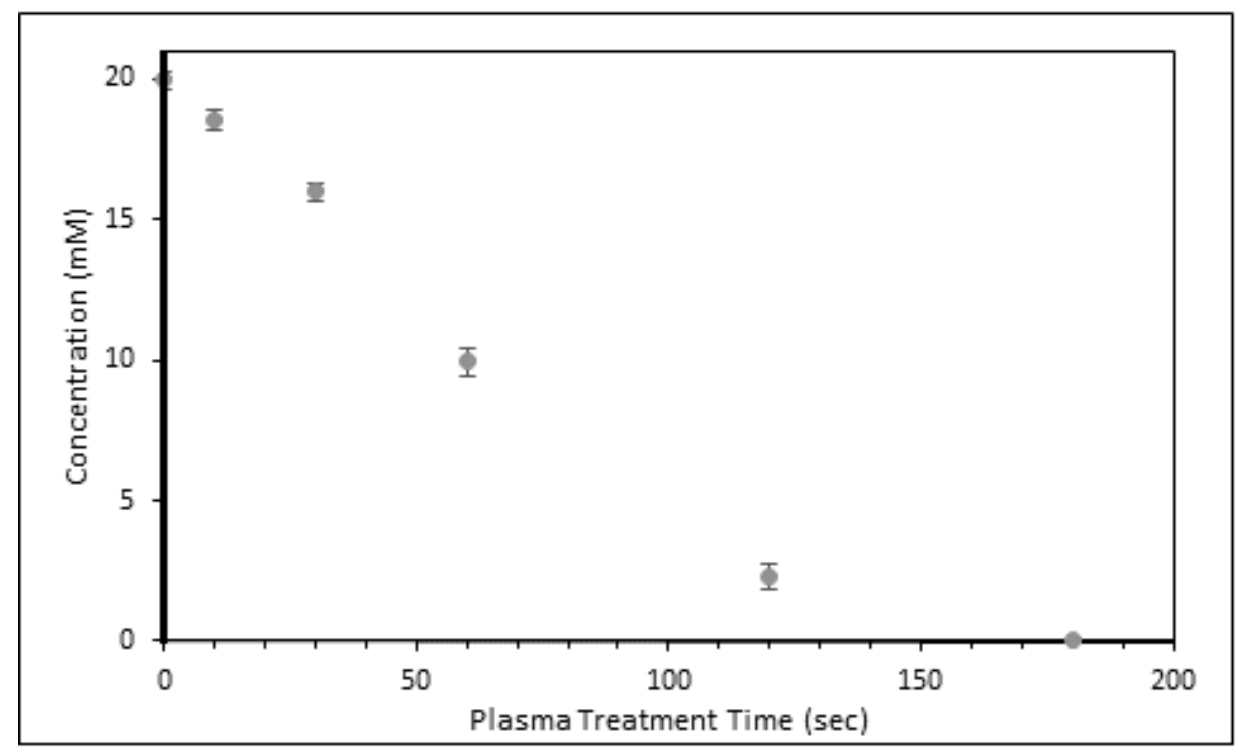

Figure 4. AMP degradation followed by integration of NMR peaks relative to the external standard caffeine.

\subsection{Mechanism of Plasma Degradation}

To better understand this degradation, high-resolution mass spectrometry was employed. The degradation of ampicillin could be followed with MS with the disappearance of the peak at $350.1178 \mathrm{~m} / z$. The first newly-formed compound visible in the MS data was the formation of ampicillin S-oxide $(366.1116 \mathrm{~m} / \mathrm{z})$. The S-oxide was further verified with MS by the presence of a peak at 
$349.0853 \mathrm{~m} / \mathrm{z}$ which signifies the loss of the amine functionality (Figure 5). As plasma time increased, the signal at $366 \mathrm{~m} / z$ also significantly increased with the fragmentation of the amine maintaining a similar ratio to the height of the $\mathrm{M}^{+}$peak.

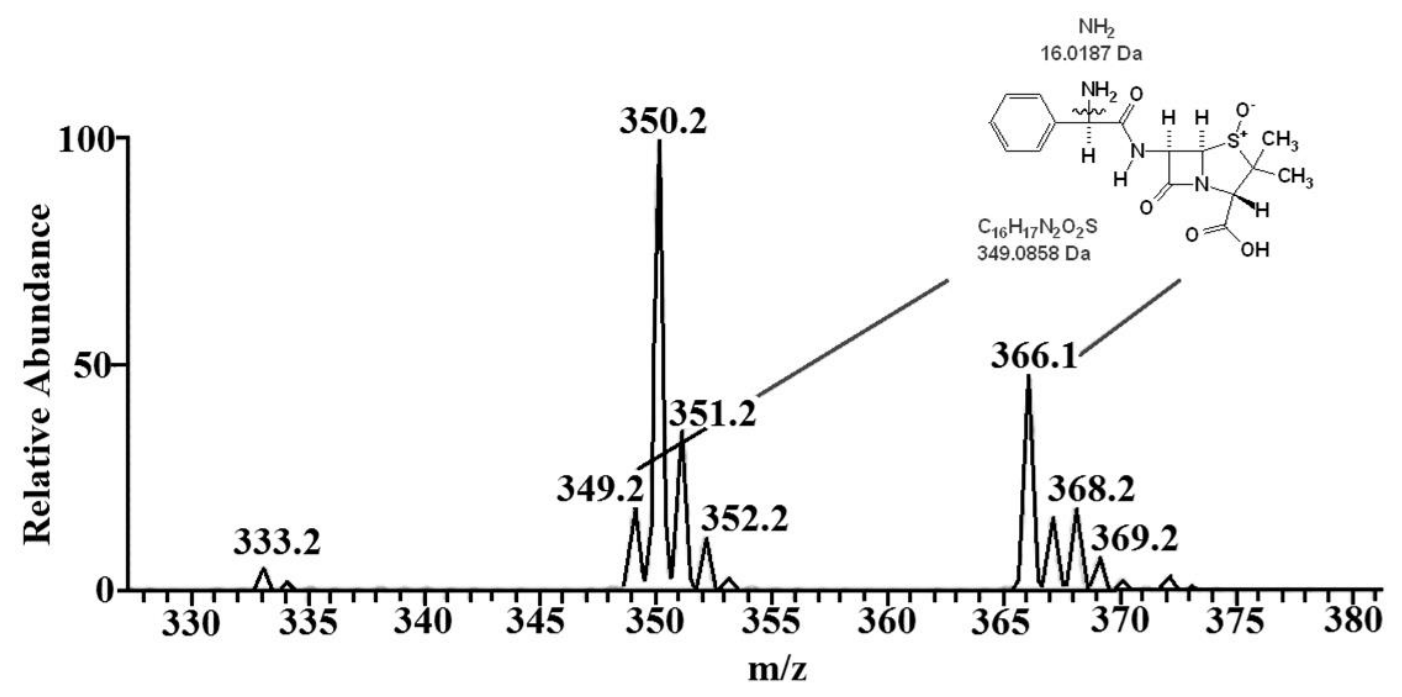

Figure 5. MS data of 1-min plasma-treated AMP verifying the presence of the ampicillin S-oxide.

A plasma treatment of 3 min showed a significant decrease in the height of this 349 peak (Figure 6). Following 5 min of treatment, this signal was almost obsolete. This suggests that something else is occurring to the ampicillin S-oxide that changes the structure, but has the same exact mass. Investigations into the literature revealed the presence of a fluorescent compound as a result of ampicillin degradation and this was attributed to the formation of ampicillin diketopiperazine [56]. At this length of a treatment time, the solutions turned yellow in color.

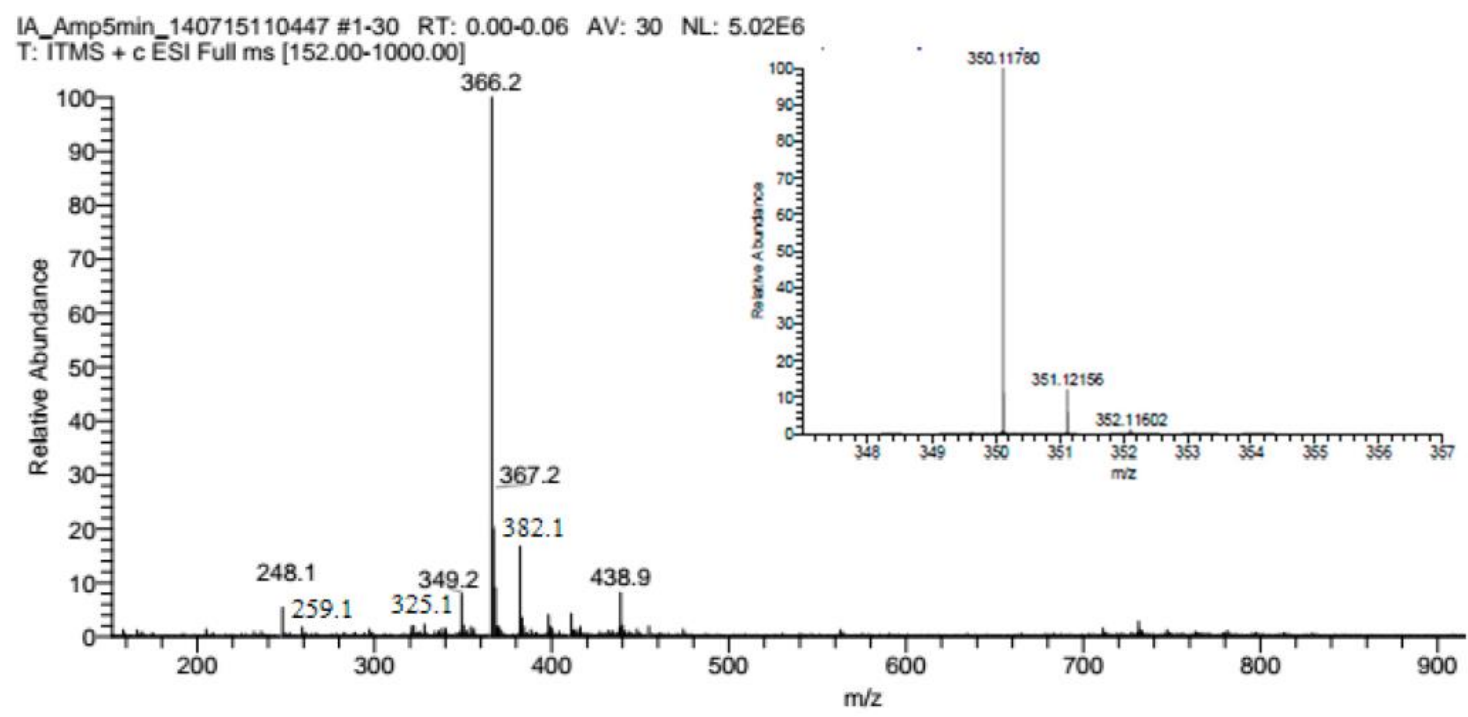

Figure 6. MS data for 3-min plasma treated AMP solutions. The insert shows the MS spectrum of AMP before exposure to plasma.

Fluorescence studies were carried out and a clear fluorescence was observed (Figure 7). This suggests that the Amp-S-oxide undergoes a rearrangement to the diketopiperazine form. The formation is possible from the opening of the $\beta$-lactam ring followed by a ring closure reaction. Further verification was possible by detecting the presence of the two signals as a result of the 
AMP-S-oxide diketopiperazine fragmentation at 191.0815 and $176.0498 \mathrm{~m} / \mathrm{z}$. The pathway is shown in Figure 8. Additional verification was monitored using FTIR by the disappearance of the signal at $1764 \mathrm{~cm}^{-1}$, representative of the $\beta$-lactam carbonyl [55].

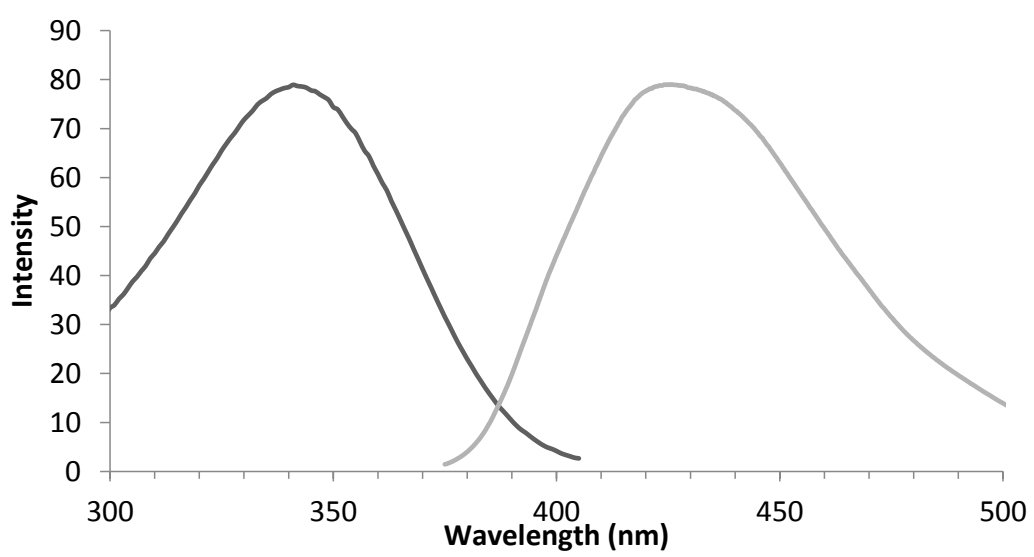

Figure 7. UV-VIS (left) and fluorescence (right) spectra of 3-min plasma-treated AMP solutions.

Ampicilloic acid $(368.1275 \mathrm{~m} / \mathrm{z})$ was detectable in minor amounts. From increasing plasma treatment times, this peak was never found to significantly increase in amount. This suggests that further plasma treatment either did not favor this degradation pathway, or additional rapid reactions occur whenever this compound was present. Further investigating this with high-resolution MS showed that the ampicilloic acid likely reacted rapidly in a number of pathways. These suggested pathways are shown in Figure 8 on the right side of the mechanism. It is likely that the newly-formed carboxylic acid is highly reactive and either fragments to form the new compounds, as shown, or follows the pathway to the formation of the diketopiperazine. If the carboxylic acid is released as $\mathrm{CO}_{2}$, this could explain for the large signal at $259.0899 \mathrm{~m} / \mathrm{z}$, which has been observed as a fragment in previous MS studies in the literature [57]. All of this work can be summarized by the pathway shown in Figure 8. The end structure seems to belong to that of the diketopiperazine of the ampicillin s-oxide. It should be noted that the UV photons in the DBD can also degrade organic chemicals [58,59], although the DBD ROS/RNS species seemed sufficient for the degradation of AMP in solutions.

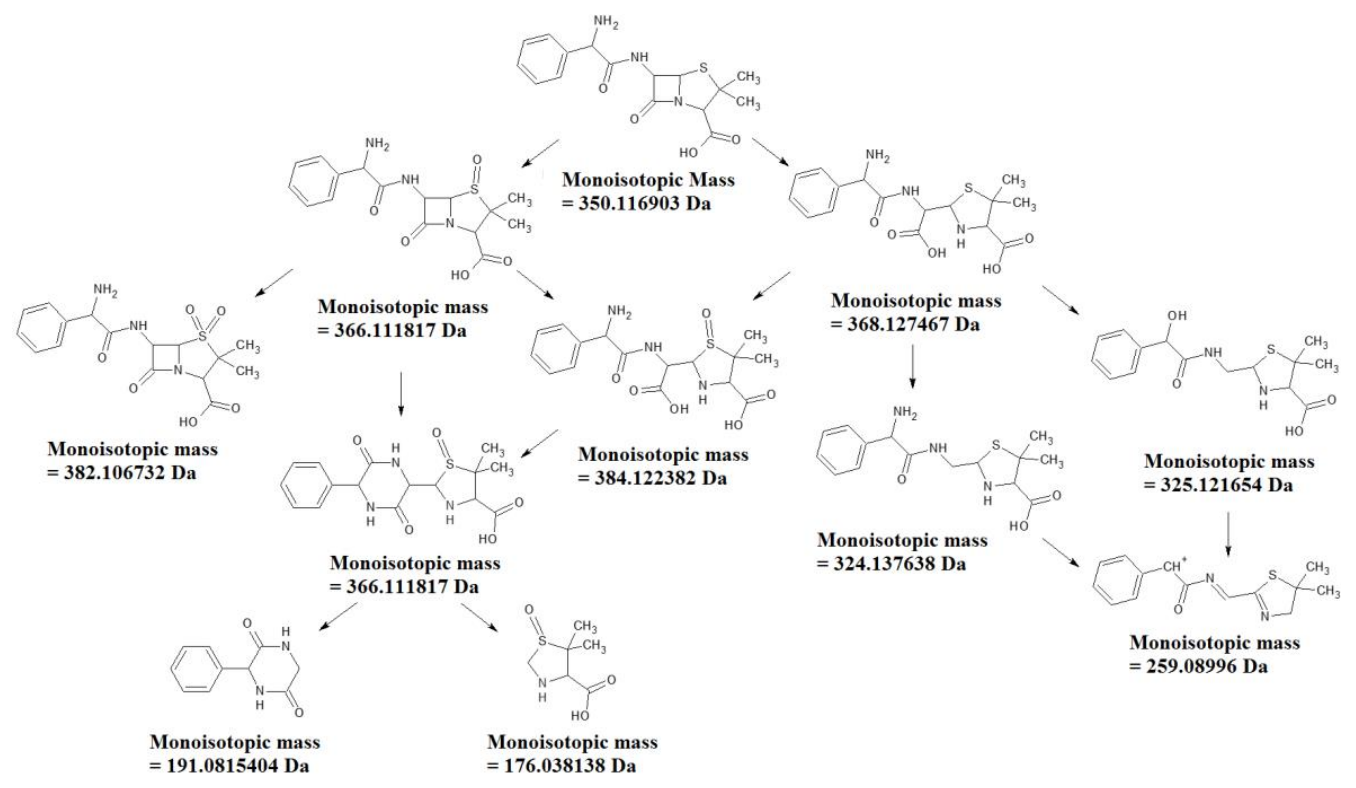

Figure 8. Mechanism of AMP degradation from plasma treatment. 


\subsection{Efficiency Comparison}

A comparison has been made to other studies in which removal of ampicillin has been investigated (Table 1). The quickest treatment time of 2 min for degradation was observed with Fenton and Photo-Fenton reactions that involve an iron catalyst with hydrogen peroxide for oxidation of the contaminants [60]. The major difference between these treatment methods and the plasma treatment is that the concentration used in our studies is more than $60 \times$ larger than what was investigated by Elmolla and Chaudhuri [60]. It is highly probable that running this at similarly low concentrations would provide a much quicker degradation. This would also likely narrow the number of remaining components in the solution. Optimization of this method in an oxygen environment is currently underway. Overall, the plasma method showed the potential for effective removal of ampicillin compared to other methods.

Table 1. Compiled investigations into ampicillin removal for wastewater cleaning comparing a variety of methods in comparison to FE-DBD air plasma treatment.

\begin{tabular}{|c|c|c|c|}
\hline Concentration & Treatment & Result & Reference \\
\hline $20 \mathrm{mg} / \mathrm{L}$ & Removal using Metallic Iron & Complete removal after $3 \mathrm{~h}$ & Ghauch et al. (2009) [61] \\
\hline $105 \mathrm{mg} / \mathrm{L}$ & Fenton & $\begin{array}{c}\text { Optimal conditions, } 2 \text { min } \\
\text { degradation }\end{array}$ & Elmolla and Chaudhuri (2009) [60] \\
\hline $105 \mathrm{mg} / \mathrm{L}$ & Photo-Fenton & $\begin{array}{c}\text { Optimal conditions, } 2 \mathrm{~min} \\
\text { degradation }\end{array}$ & Elmolla and Chaudhuri (2009) [60] \\
\hline $105 \mathrm{mg} / \mathrm{L}$ & $\begin{array}{l}\text { Semiconductor } \\
\text { Photocatalysis }\end{array}$ & With 180 min irradiation time & Elmolla and Chaudhuri (2010) [60] \\
\hline $\begin{array}{l}1.6 \mathrm{mg} / \mathrm{L} \\
6.99 \mathrm{~g} / \mathrm{L}\end{array}$ & $\begin{array}{l}\text { Chlorination } \\
\text { Air plasma in this work }\end{array}$ & $\begin{array}{l}\text { Possible total degradation after } 2 \mathrm{~h} \\
* \text { complete removal after } 3 \mathrm{~min}\end{array}$ & Navalon et al. (2008) [62] \\
\hline
\end{tabular}

\section{Conclusions}

This work shows the effective degradation of ampicillin with air plasma treatment. No ampicillin was found to exist following 3-min of plasma treatment from NMR studies. A full verification was performed using high-res MS and verified that only a minimal amount existed after three minutes, however, no AMP was detectible after 5-min treatment times. The work demonstrated that the non-thermal DBD plasma approach is effective to remove antibiotics from wastewater.

Acknowledgments: We thank Keck Foundation for partial support of the project. Haifeng Ji also thanks the Beijing Natural Science Foundation of China (KZ201610015014) for financial support.

Author Contributions: Joshua B. Smith, Isaac Adams and Hai-Feng Ji conceived and designed the experiments and wrote the paper; Joshua B. Smith and Isaac Adams performed the experiments and analyzed the data.

Conflicts of Interest: The authors declare no conflict of interest.

\section{References}

1. Risk of Birth Defects Due to Certain Antibiotics During Pregnancy. Available online: http:/ / psychomotor4. rssing.com / browser.php?indx=3809892\&last=1\&item=12 (accessed on 8 August 2017).

2. National Action Plan for Combating Antibotic-Resistant Bacteria. Available online: https://www. cdc.gov/drugresistance/pdf/national_action_plan_for_combating_antibotic-resistant_bacteria.pdf (accessed on 8 August 2017).

3. Kolpin, D.W.; Furlong, E.T.; Meyer, M.T.; Thurman, E.M.; Zaugg, S.D.; Barber, L.B.; Buxton, H.T. Pharmaceuticals, hormones, and other organic wastewater contaminants in U.S. streams, 1999-2000: A national reconnaissance. Environ. Sci. Technol. 2002, 36, 1202-1211. [CrossRef] [PubMed]

4. Kümmerer, K. Antibiotics in the aquatic environment-A review-Part II. Chemosphere 2009, 75, 435-441. [CrossRef] [PubMed]

5. Fatta-Kassinos, D.; Meric, S.; Nikolaou, A. Pharmaceutical residues in environmental waters and wastewater: Current state of knowledge and future research. Anal. Bioanal. Chem. 2011, 399, 251-275. [CrossRef] [PubMed] 
6. Diaz-Cruz, M.S.; Lopez de Alda, M.J.; Barcelo, D. Environmental behavior and analysis of veterinary and human drugs in soils, sediments and sludge TrAC. Trends Anal. Chem. 2003, 22, 340-351. [CrossRef]

7. Brown, K.D.; Kulis, J.; Thomson, B.; Chapman, T.H.; Mawhinney, D.B. Occurrence of antibiotics in hospital, residential, and dairy effluent, municipal wastewater, and the Rio Grande in New Mexico. Sci. Total Environ. 2006, 366, 772-783. [CrossRef] [PubMed]

8. Czekalski, N.; Berthold, T.; Caucci, S.; Egli, A.; Bürgmann, H. Increased levels of multiresistant bacteria and resistance genes after wastewater treatment and their dissemination into Lake Geneva, Switzerland. Front. Microbiol. 2012, 3, 1-18. [CrossRef] [PubMed]

9. Antibiotic Resistance from Unexpected Sources-Herbicides, Dust and Metals. Available online: http:/ / www.forbes.com/sites/judystone/2015/04/01/antibiotic-resistance-from-unexpected-sources / (accessed on 8 August 2017).

10. Rogers, H.R. Behavior and fate of organic contaminants during sewage treatment and in sewage sludges. Sci. Total Environ. 1996, 185, 3-26. [CrossRef]

11. Zhang, G.; Ji, S.; Xi, B. Feasibility study of treatment of amoxillin wastewater with a combination of extraction, Fenton oxidation and reverse osmosis. Desalination 2006, 196, 32-42. [CrossRef]

12. Li, S.; Li, X.; Wang, D. Membrane (RO-UF) filtration for antibiotic wastewater treatment and recovery of antibiotics. Sep. Purif. Technol. 2004, 34, 109-114. [CrossRef]

13. Aksu, Z.; Tunç, O. Application of biosorption for penicillin $\mathrm{G}$ removal: Comparison with activated carbon. Process Biochem. 2005, 40, 831-847. [CrossRef]

14. Westerhoff, P.; Yoon, Y.; Snyder, S.; Wert, E. Fate of endocrine-disruptor, pharmaceutical, and personal care product chemicals during simulated drinking water treatment processes. Environ. Sci. Technol. 2005, 39, 6649-6663. [CrossRef] [PubMed]

15. Putra, E.K.; Pranowo, R.; Sunarso, J.; Indraswati, N.; Ismadji, S. Performance of activated carbon and bentonite for adsorption of amoxicillin from wastewater: Mechanisms, isotherms and kinetics. Water Res. 2009, 43, 2419-2430. [CrossRef] [PubMed]

16. Rivera-Utrilla, J.; Prados-Joya, G.; Sánchez-Polo, M.; Ferro-García, M.A.; Bautista-Toledo, I. Removal of nitroimidazole antibiotics from aqueous solution by adsorption/bioadsorption on activated carbon. J. Hazard. Mater. 2009, 170, 298-305. [CrossRef] [PubMed]

17. Legrini, O.; Oliveros, E.; Braunm, A.M. Photochemical processes for water treatment. Chem. Rev. 1993, 93, 671-698. [CrossRef]

18. Malato, S.; Fernández-Ibáñez, P.; Maldonado, M.I.; Blanco, J.; Gernjak, W. Decontamination and disinfection of water by solar photocatalysis: Recent overview and trends. Catal. Today 2009, 147, 1-59. [CrossRef]

19. Tekin, H.; Bilkay, O.; Ataberk, S.S.; Balta, T.H.; Ceribasi, I.H.; Sanin, F.D. Use of Fenton oxidation to improve the biodegradability of a pharmaceutical wastewater. J. Hazard. Mater. 2006, 136, 258-265. [CrossRef] [PubMed]

20. Melero, J.A.; Calleja, G.; Martinez, F.; Molina, R.; Pariente, M.I. Nanocomposite $\mathrm{Fe}_{2} \mathrm{O}_{3} / \mathrm{SBA}-15$ : An efficient and stable catalyst for the catalytic wet peroxidation of phenolic aqueous solutions. Chem. Eng. J. 2007, 131, 245-256. [CrossRef]

21. Santos, A.; Yustos, P.; Rodriguez, S.; Simon, E.; Garcia-Ochoa, F. Abatement of phenolic mixtures by catalytic wet oxidation enhanced by Fenton's pretreatment: Effect of $\mathrm{H} 2 \mathrm{O} 2$ dosage and temperature. J. Hazard. Mater. 2007, 146, 595-601. [CrossRef] [PubMed]

22. Dickenson, E.R.V.; Drewes, J.E.; Sedlak, D.L.; Wert, E.C.; Snyder, S.A. Applying surrogates and indicators to assess removal efficiency of trace organic chemicals during chemical oxidation of wastewaters. Environ. Sci. Technol. 2009, 43, 6242-6247. [CrossRef] [PubMed]

23. Hapeshi, E.; Achilleos, A.; Vasquez, M.I.; Michael, C.; Xekoukoulotakis, N.P.; Mantzavinos, D.; Kassinos, D. Drugs degrading photocatalytically: Kinetics and mechanisms of ofloxacin and atenolol removal on titania suspensions. Water Res. 2010, 44, 1737-1746. [CrossRef] [PubMed]

24. Schiavello, M. Some working principles of heterogeneous photocatalysis by semiconductors. Electrochim. Acta 1993, 38, 11-14. [CrossRef]

25. Naddeo, V.; Meric, S.; Kassinos, D.; Belgiorno, V.; Guida, M. Fate of pharmaceuticals in contaminated urban wastewater effluent under ultrasonic irradiation. Water Res. 2009, 43, 4019-4027. [CrossRef] [PubMed]

26. Adams, C.; Asce, M.; Wang, Y.; Loftin, K.; Meyer, M. Removal of antibiotics from surface and distilled water in conventional water treatment processes. J. Environ. Eng. 2002, 1282, 253-260. [CrossRef] 
27. Ryan, C.C.; Tan, D.T.; Arnold, W.A. Direct and indirect photolysis of sulfamethoxazole and trimethoprim in wastewater treatment plant effluent. Water Res. 2011, 45, 1280-1286. [CrossRef] [PubMed]

28. Balcioglu, I.A.; Otker, M. Treatment of pharmaceutical wastewater containing antibiotics by $\mathrm{O}_{3}$ and $\mathrm{O}_{3} / \mathrm{H}_{2} \mathrm{O}_{2}$ processes. Chemosphere 2003, 50, 85-95. [CrossRef]

29. Arslan, A.I.; Dogruel, S.; Baykal, E.; Gerone, G. Combined chemical and biological oxidation of penicillin formulation effluent. J. Environ. Manag. 2004, 73, 155-163.

30. Andreozzi, R.; Canterino, M.; Marotta, M.; Paxeus, N. Antibiotic removal from wastewaters: The ozonation of amoxicillin. J. Hazard. Mater. 2005, 122, 243-250. [CrossRef] [PubMed]

31. Homem, V.; Santos, L. Degradation and removal methods of antibiotics from aqueous matrices-A review. J. Environ. Manag. 2011, 92, 2304-2347. [CrossRef] [PubMed]

32. Kim, G.C.; Lee, H.W.; Byun, J.H.; Chung, J.; Jeon, Y.C.; Lee, J.K. Dental applications of low-temperature nonthermal plasmas. Plasma Process. Polym. 2013, 10, 199-206. [CrossRef]

33. Hollender, J.; Zimmermann, S.G.; Koepke, S.; Krauss, M.; McArdell, C.S.; Ort, C.; Singer, H.; von Gunten, U.; Siegrist, H. Elimination of organic micropollutants in a municipal wastewater treatment plant upgraded with a full-scale post-ozonation followed by sand filtration. Environ. Sci. Technol. 2009, 43, 7862-7869. [CrossRef] [PubMed]

34. Li, Y.; Friedman, G.; Brooks, A.; Fridman, A.; Ji, H.-F. Decomposition of Sugars under Non-Thermal Dielectric Barrier Discharge Plasma. Clinical Plasma Medicine. 2014, 2, 56-63. [CrossRef]

35. Misra, N.N.; Pankaj, S.K.; Walsh, T.; O’Regan, F.; Bourke, P.; Cullen, P.J. In-package nonthermal plasma degradation of pesticides on fresh produce. J. Hazard. Mater. 2014, 271, 33-40. [CrossRef] [PubMed]

36. Tiede, R.; Hirschberg, J.; Daeschlein, G.; von Woedtke, T.; Vioel, W.; Emmert, S. Plasma Applications: A Dermatological View. Contrib. Plasma Phys. 2014, 54, 118-130. [CrossRef]

37. Locke, B.R.; Sato, M.; Sunka, P.; Hoffmann, M.R.; Chang, J.-S. Electrohydraulic Discharge and Nonthermal Plasma for Water Treatment. Ind. Eng. Chem. Res. 2006, 45, 882-905. [CrossRef]

38. Tichonovas, M.; Krugly, E.; Racys, V.; Hippler, R.; Kauneliene, V.; Stasiulaitiene, I.; Martuzevicius, D. Degradation of Various Textile Dyes as Wastewater Pollutants under Dielectric Barrier Discharge Plasma Treatment. Chem. Eng. J. 2013, 229, 9-19. [CrossRef]

39. Fridman, G.; Peddinghaus, M.; Ayan, H.; Fridman, A.; Balasubramanian, M.; Gutsol, A.; Brooks, A.; Friedman, G. Blood coagulation and living tissue sterilization by floating-electrode dielectric barrier discharge in air. Plasma Chem. Plasma Process. 2006, 26, 425-442. [CrossRef]

40. Fridman, G.; Brooks, A.D.; Balasubramanian, M.; Fridman, A.; Gutsol, A.; Vasilets, V.N.; Ayan, H.; Friedman, G. Comparison of direct and indirect effects of non-thermal atmospheric-pressure plasma on bacteria. Plasma Process. Polym. 2007, 4, 370-375. [CrossRef]

41. Nehra, V.; Kumar, A.; Dwivedi, H.K. Atmospheric nonthermal plasma sources. Int. J. Eng. 2008, 2, $53-68$.

42. Ayan, H.; Staack, D.; Fridman, G.; Gutsol, A.; Muhkin, Y.; Starikovskii, A.; Fridman, A.; Friedman, G. Application of nanosecond-pulsed dielectric barrier discharge for biomedical treatment of topographically non-uniform surfaces. J. Phys. D 2009, 42, 125202. [CrossRef]

43. Joshi, S.G.; Cooper, M.; Yost, A.; Paff, M.; Ercan, U.K.; Fridman, G.; Friedman, G.; Fridman, A.; Brooks, A.D. Nonthermal dielectric-barrier discharge plasma-induced inactivation involves oxidative DNA damage and membrane lipid peroxidation in Escherichia coli. Antimicrob. Agents Chemother. 2011, 55, 1053-1062. [CrossRef] [PubMed]

44. Miao, H.; Yun, G.H. The sterilization of Escherichia coli by dielectric-barrier discharge plasma at atmospheric pressure. Appl. Surf. Sci. 2011, 257, 7065-7070. [CrossRef]

45. Robinson-Fuentes, V.A.; Jefferies, T.M.; Branch, S.K. Degradation pathways of ampicillin in alkaline solutions. J. Pharm. Pharmacol. 1997, 49, 843-851. [CrossRef] [PubMed]

46. Massé, D.L.; Cata Saady, N.M.; Gilbert, Y. Potential of Biological Processes to Eliminate Antibiotics in Livestock Manure: An Overview. Animals 2014, 4, 146-163. [CrossRef] [PubMed]

47. Goossens, H.; Ferech, M.; Vanderstichele, R.; Elseviers, M. Outpatient antibiotic use in Europe and association with ESAC Project Group. Lancet 2005, 365, 579-587. [CrossRef]

48. Branch, S.K.; Casy, A.F.; Ominde, E.M.A. Application of 1H nuclear magnetic resonance spectroscopy to the analysis of beta-lactam antibiotics and their common degradation products. J. Pharm. Biomed. Anal. 1987, 5, 73-103. [CrossRef] 
49. Magureanua, M.; Piroia, D.; Mandachea, N.B.; Davidb, V.; Medvedovicib, A.; Braduc, C.; Parvulescuc, V.I. Degradation of antibiotics in water by non-thermal plasma treatment. Water Res. 2011, 45, 3407-3416. [CrossRef] [PubMed]

50. Li, Y.; Kojtari, A.; Friedman, G.; Brooks, A.D.; Fridman, A.; Ji, H.F. Decomposition of 1-Valine under Nonthermal Dielectric Barrier Discharge Plasma. J. Phys. Chem. B 2014, 118, 1612-1620. [CrossRef] [PubMed]

51. Liu, C.; Dobrynin, D.; Fridman, A. Uniform and non-uniform modes of nanosecond-pulsed dielectric barrier discharge in atmospheric air: Fast imaging and spectroscopic measurements of electric field. J. Phys. D 2014, 47, 252003. [CrossRef] [PubMed]

52. Bird, A.E.; Steele, B.R.; Boles, M.O.; Gane, P.A.C. Nuclear magnetic resonance and circular dichroism of penicillins derived from disubstituted acetic acids. J. Chem. Soc. Perkin Trans. 1 1982, 563-569. [CrossRef]

53. Gozlan, I.; Rotstein, A.; Avisar, D. Investigation of an amoxicillin oxidative degradation product formed under controlled environmental conditions. Environ. Chem. 2010, 7, 435-442. [CrossRef]

54. Micetich, R.G. A Convenient Synthesis of Ampicillin Sulfoxide and 6-Aminopenicillanic Acid Sulfoxide. Synthesis 1976, 1976, 264-265. [CrossRef]

55. Gunasekaran, S.; Varadhan, S.R.; Karunanidhi, N. Qualitative analysis on the infrared bands of tetracycline and ampicillin. Proc. Indian Natl. Sci. Acad. A 1996, 62, 309-316.

56. Hou, J.P.; Poole, J.W. Kinetics and mechanism of degradation of ampicillin in solution. J. Pharm. Sci. 1969, 58, 447-454. [CrossRef] [PubMed]

57. Li, T.; Xu, X.; Fu, S.; Zhang, J.; Zhang, K.; Wang, S.; Zhao, M.; Ding, W.; Wang, Q. Structural elucidation of stress degradation products of ampicillin sodium by liquid chromatography/hybrid triple quadrupole linear ion trap mass spectrometry and liquid chromatography/hybrid quadrupole time-of-flight mass spectrometry. Rapid Commun. Mass Spectrom. 2014, 28, 1929-1936. [CrossRef] [PubMed]

58. Vandamme, M.; Robert, E.; Pesnel, S. Antitumor effect of plasma treatment on U87 glioma xenografts: Preliminary results. Plasma Process Polym. 2010, 7, 264-273. [CrossRef]

59. Boudam, M.K.; Moisan, M.; Saoudi, B.; Popovici, C.; Gherardi, N.; Massines, F. Bacterial spore inactivation by atmospheric-pressure plasmas in the presence or absence of UV photons as obtained with the same gas mixture. J. Phys. D 2006, 39, 3494. [CrossRef]

60. Elmolla, E.S.; Chaudhuri, M. Degradation of the antibiotics amoxicillin, ampicillin and cloxacillin in aqueous solution by the photo-Fenton process. J. Hazard. Mater. 2009, 172, 1476-1481. [CrossRef] [PubMed]

61. Ghauch, A.; Tuqan, A.; Assi, H.A. Antibiotic removal from water: elimination of amoxicillin and ampicillin by microscale and nanoscale iron particles. Environ Pollut. 2009, 157, 1626-1635. [CrossRef] [PubMed]

62. Navalon, S.; Alvaro, M.; Garcia, H. Reaction of chlorine dioxide with emergent water pollutants: Product study of the reaction of three beta-lactam antibiotics with $\mathrm{ClO}_{2}$. Water Res. 2008, 42, 1935-1942. [CrossRef] [PubMed]

(C) 2017 by the authors. Licensee MDPI, Basel, Switzerland. This article is an open access article distributed under the terms and conditions of the Creative Commons Attribution (CC BY) license (http://creativecommons.org/licenses/by/4.0/). 